\title{
LUDOWE PAŃSTWO DOBROBYTU
}

\author{
ANNA PIEKARSKA
}

\begin{abstract}
Abstrakt: Artykuł stanowi próbę rekonstrukcji przemian praw ubogich w Anglii w okresie prekapitalistycznym w oparciu o pracę Lorie Charlesworth Welfare's Forgotten Past. Istotnym kontekstem, w jakim osadzona jest niniejsza rekonstrukcja, jest historia grodzeń i dóbr wspólnych (commons), a także wywodząca się od Karola Marksa koncepcja tak zwanej akumulacji pierwotnej. Szczególną uwagę poświęcam splotowi dwóch zjawisk: utraty podmiotowych praw ubogich i ich penalizacji w formie karania za włóczęgostwo.
\end{abstract}

Słowa kluczowe: Lorie Charlesworth, grodzenia, ubodzy, dobra wspólne, historia prawa, Anglia 
Książka Lorie Charlesworth Welfare's Forgotten Past: A Socio-Legal History of the Poor Law stanowi próbę rzucenia nowego światła na instytucję państwa opiekuńczego i historię opieki nad ubogimi. Narracja autorki przeciwstawia się wizji będącej rdzeniem wciąż popularnej polityki „zero tolerancji”, przedstawiającej ubogich jako leniwą podklasę, underclass o skłonnościach przestępczych i jednocześnie projektującej obraz państwa jako instancji oceniającej i korygującej za pomocą dostępnych mu narzędzi postawę biedoty (por. Tosi 1996). O ile jednak sam przedmiot polemiki i stawiane wobec niego zarzuty - przyjmujące postać krytyki uznania biednych za zbędny element populacji i związanych z tym prób czy to biopolitycznego zarządzania (Katrougalos i Lazaridis 2003; Musterd i Ostendorf 2003), czy penalizacji i inkarceracji (Hüning 2015; Wacquant 2009) - nie sa niczym nowym, to o oryginalności pracy Charlesworth stanowi przyjęta przez nia perspektywa. Autorka skupia się bowiem na jurydycznej analizie przemian osobistych uprawnień ubogich, jednocześnie starając się odzyskać tytułową „zapomnianą przeszłość” i pokazać zasadnicze przekłamanie tkwiące u podstaw negatywnie rozumianej polityki postępowania wobec biednych, tym samym dekonstruując jej wspomniane wcześniej założenia. Dociekania zorganizowane są wokół tezy o substancjalnej zmianie pozycji ubogich - ich przemianie z aktywnych, obdarzonych możliwością działania podmiotów w pasywne przedmioty zarządzania pozbawione zdolności do samodecydowania i samodzielnego utrzymywania się.

Głównym przedmiotem dociekań Charlesworth sa przekształcenia, które dokonały się w obrębie angielskiego prawa do zapomogi, przysługującego tym, którzy w niezawiniony sposób utracili środki umożliwiające samodzielne utrzymanie się (destitute). Wybór argumentowany jest długa tradycją pomocy biednym w Anglii, jak również wpływem tamtejszych rozwiązań na inne systemy opieki społecznej. Książka oferuje dwupoziomowa rekonstrukcję historii rzeczonego prawa (Charlesworth 2010, 2) - przytoczone zostają zarówno doktrynalne spory i jurydyczne definicje (por. rozdziały 3, 4, 8), jak i mikrohistoryczne źródła obrazujące to, jak sami uprawnieni rozumieli przysługujące im uprawnienie (por. rozdziały 5, 9, 10). Te uzupełniające się perspektywy służą wykazaniu sformalizowanego charakteru prawa ubogich, co stanowi jeden z głównych celów Welfare’s Forgotten Past. Cel ten może z początku wydawać się bliski dążeniom Marksa z serii artykułów opublikowanych w Rheinische Zeitung, szczególnie tych poświęconych kwestii kradzieży drewna (por. Marks 1976). Należy jednak podkreślić, że intencje stojące za każdym z tych tekstów oraz ich stawki są zupełnie inne: Marks stara się wykazać, że zwyczaj ubogich może być rozumniejszy niż ustawa, którą ,interes prywatny przekształca [...] w szçurołapa" (Marks i Engels 1976, 145), tym samym pozbawiając ja zarówno racjonalności, jak i powszechnego charakteru. Charlesworth natomiast udowadnia, że obok wielu praw zwyczajowych przysługującym drobnemu chłopstwu i biedocie, które pomagały w samodzielnym utrzymaniu się - przykładowo prawa do zbierania pokłosia po 
żniwach, janowca, jagód i żołędzi, wypasania bydła, wycinki złóż torfu (Charlesworth 2010, 38) - istniało realne uprawnienie do zapomogi, zapisane w angielskim porządku jurydycznym.

Uprawnienie to, mimo że zachowywało aż do dziewiętnastego wieku stosunkowo homogeniczną treść, miało różnorodne źródła prawne, ulegające zmianom na przestrzeni lat (Charlesworth 2010, 35-59). Zmiany te, aż do całkowitej implementacji nowego prawa ubogich z 1834 roku, zasadniczo nie wpływały na kształt systemu opieki nad biednymi, który możemy scharakteryzować w następujący sposób: po pierwsze, uprawnienie do zapomogi miało formę lokalną i autonomiczną, przez co mylnie odmawiano mu charakteru powszechnego. Realizacja rozpatrywanego tu prawa możliwa była tylko w parafiach, które, wbrew dzisiejszemu rozumieniu tego słowa, w okresie interesującym autorkę stanowiły zeświecczoną jednostkę podziału administracyjnego Anglii i Walii. Zapomoga była udzielana ze środków parafii, to jest „warunkowanego przez zapotrzebowanie lokalnego funduszu, nieograniczonego i otwartego systemu niezależnego od rządowych ograniczeń finansowych” (Charlesworth 2010, 140), którego źródłem był rokrocznie ustalany przez samą radę parafialną podatek. Uznanie lub nieuznanie ubiegającego się o zapomogę za znajdującego się w niezawinionym niedostatku ${ }^{1}$, a tym samym odmowa pomocy bądź jej przyznanie i ustalenie jej wysokości stanowiły elementy dyskrecjonalnej władzy parafialnego urzędnika ${ }^{2}$. Od jego decyzji przysługiwało jednak odwołanie do Sędziego Pokoju. Należy podkreślić, że długość procedury odwoławczej zależna była od sytuacji ubiegającego się o pomoc - parafie nie mogły dopuścić do śmierci głodowej wnioskodawcy w trakcie przedłużającego się postępowania (Charlesworth 2010, 52). Za niedopatrzenia i nieprawidłowości urzędnicy ponosili odpowiedzialność osobistą odpowiadać mogli nawet za nieumyślne spowodowanie śmierci. Możliwość efektywnego egzekwowania prawa, gwarantowanego przez instancyjność procesu i odgórnie określone obowiązki parafii, stanowi zdaniem Charlesworth dowód na to, że zapewnianie pomocy ubogim było rozpoznawane jako element systemu prawnego i jako taki funkcjonowało. Gdyby tak nie było, „wiele obszarów nie wspomagałoby biednych, a społeczna historia Anglii wyglądałaby zupełnie inaczej" (Charlesworth 2010, 135).

Po drugie, prawo do zapomogi w niedostatku powiązane było z ustawami o osadnictwie (laws of settlement) - o wsparcie można się było ubiegać tylko w tej parafii, w której było się osiedlonym. Ten wymóg generował liczne trudności: podane miejsce osiedlenia zawsze mogło być zakwestionowane przez urzędników, co prowadziło do wszczynania przez parafię długotrwałego śledztwa w celu ustalenia właściwej lokalizacji. Jeżeli była inna od miejsca

\footnotetext{
${ }^{1}$ Podobnie jak w przypadku innych warunków udzielenia pomocy trudno wskazać tutaj jasne kryteria winy bądź jej braku. Subiektywnej ocenie urzędnika podlegało to, czy wnioskujący uchyla się od pracy i czy jest do niej zdolny oraz czy świadomie doprowadził do powstania sytuacji niedostatku (na przykład trwoniąc środki utrzymania).

${ }^{2}$ Urzędnicy parafialni byli wybierani corocznie przez radę parafialna. Nie pobierali żadnego wynagrodzenia za pracę (Charlesworth 2001, 169).
} 
pobytu, to urzędnikom przysługiwało prawo odesłania (removal) osoby w niedostatku, w celu odciążenia parafialnego funduszu. Oznaczało to także, że odmawiano pomocy osobom nieosiedlonym w Anglii i Walii. Same regulacje dotyczące osiedlania się były natomiast niejasne i kazuistyczne - świadczy o tym przywoływane przez Charlesworth stwierdzenie: „ustawa o osiadłości »była (prawdopodobnie) bardziej zyskowna dla profesji prawniczej niż jakikolwiek inny element angielskiej jurysprudencji«" (Eden 1797 w: Charlesworth 2010, 35). Wskazane wyżej wady wymogu osiadłości kładą się cieniem na prawie ubogich, osłabiając jednocześnie jego skuteczność. Autorka przywołuje liczne stanowiska negatywnie odnoszące się do obowiązku posiadania osiedlenia jako do środka służącego pozbywaniu się ubogich, usprawiedliwieniu odmowy pomocy czy wreszcie biopolitycznej kontroli i nadzorowi nad ubogimi, ograniczającemu ich mobilność (Charlesworth 2010, 74-104). Ślady tego ostatniego sposobu ujmowania problemu możemy znaleźć zresztą u Marksa w Kapitale, gdzie porównuje on wpływ ustaw o osiadłości do wpływu „ukazu Tatara Borysa Godunowa ${ }^{3}$ na los chłopstwa rosyjskiego" (Marks 1951, 781). Dlaczego więc autorka decyduje się bronić obowiązku osadnictwa jako warunku sine qua non przyznania pomocy?

Charlesworth nie zaprzecza istnieniu złych praktyk opartych na wykorzystywaniu obowiązku osadnictwa przeciw samym ubogim, zaznacza jednak, że ,zapiski ukazuja przede wszystkim negatywny aspekt osiadłości, patologię postępowania prawnego, a ich wykorzystanie potwierdza patologiczne wnioski, które są przytłaczająco negatywne" (Charlesworth 2010, 83). Zauważa ponadto, że krytyka ustaw o osiadłości jako reakcyjnych i przestarzałych stanowiła jeden z głównych punktów dyskursu argumentującego za nowym prawem ubogich w dziewiętnastym wieku, który, jej zdaniem, wciąż wpływa na sposób postrzegania tych ustaw. Aby przeciwdziałać zniekształcaniu tego obrazu, autorka przedstawia rewers obowiązku osiedlenia, wykazując, że z tego tytułu gwarantowano uzyskanie zapomogi. Podkreśla, że „każdy mężczyzna i każda kobieta urodzeni w Anglii i Walii posiadali prawny status osiedlenia w jakimś [podkr. - AP] miejscu, a zatem uprawnienie do zapomogi w niedostatku" (Charlesworth 2010, 167). Rzecz jasna nie wykluczało to problemów związanych z ustaleniem miejsca osiedlenia, jednak przekonanie o możliwości uzyskania pomocy od władz lokalnych z tytułu samej przynależności narodowej stanowiło istotny element świadomości społeczno-prawnej ludności angielskiej.

O największej wadliwości opisywanego tu systemu pomocy ubogim świadczyła jednak nie opieszałość urzędników, chciwość parafian czy nawet wykluczający aspekt ustawy o osiadłości (nie należy zapominać, że nie obejmowała ona ówcześnie Irlandczyków

\footnotetext{
${ }^{3}$ W innym miejscu Marks tak opisuje ten ukaz: „Borys Godunow (ukazem z 2 listopada 1601 roku) położył kres prawu chłopstwa do przemieszczania się po Cesarstwie i przywiązał je do włości, do których przynależeli przez urodzenie czy zamieszkanie. Pod władzą jego następców władza szlachty nad chłopstwem gwałtownie wzrosła i stan poddaństwa stopniowo stał się powszechnym udziałem tych ostatnich” (Marks 1980).
} 
i Szkotów). W zakresie władzy urzędnika, poza możliwością odmowy udzielenia pomocy czy odesłania do innej parafii, leżało bowiem skierowanie danego przypadku na drogę prawnokarna. Charlesworth nie pozostawia tu złudzeń: „penalizacja biedoty ma w Anglii długa tradycję" (Charlesworth 2010, 168). Przede wszystkim należy wspomnieć o wykorzystywaniu przez urzędników przysługujących im kompetencji - w celu uniknięciu konieczności udzielenia pomocy - przez postawienie ubiegającemu się o zapomogę zarzutu włóczęgostwa (vagrancy). Konkretna osoba samym swoim wyglądem mogła ściagnąć na siebie podejrzenia o włóczęgostwo, a co za tym idzie, często także karę chłosty - pręgierz znajdował się w każdym mieście. Powszechność procederu karania osób, które nie mogły uzasadnić opuszczenia parafii swego osiedlenia, czy też po prostu nieposiadających stałego miejsca osiedlenia, potwierdza diagnozę Marksa z rozdziału o tak zwanej akumulacji pierwotnej, gdzie pisze on, że: ,groteskowoterrorystyczne ustawy wdrażały pręierzem, batem i torturą do dyscypliny pracy najemnej lud wiejski, przemocą wywłaszczony z ziemi, wygnany i obrócony w[e] włóczęgów” (Marks 1951, 796).

Charlesworth nie unika zatem opisywania elementów, które w negatywny sposób wpływały na opiekę parafialną jako instytucję. Do postępującej penalizacji biedoty na mocy surowych ustaw dotyczących włóczęgostwa (por. Marks 1951, 794-795) i uchylania się urzędników od udzielania pomocy dodaje jeszcze inne zarzuty: wspomina o procederach wywożenia niezamężnych kobiet w ciąży do innych parafii lub skłaniania ich - droga przekupstwa - do wyjazdu, w celu uniknięcia dodatkowego obciążenia funduszu dla ubogich ${ }^{4}$. Autorka piszę także o udzielaniu dzieciom licencji na żebranie, a tym samym „umożliwianiu” im samodzielnego utrzymania, a także o świadectwach upokorzeń i niechęci do biednych zawartych w bynajmniej nie sielankowym poemacie The Parish Johna Clare'a (por. Charlesworth 2001). Mimo to jednak podtrzymuje teze o substancjalnej zmianie pozycji ubogich, która w negatywny sposób odbiła się na opiece społecznej jako takiej, jak również na samych ubogich. Wiąże się to z metodologia przyjęta przez Charlesworth, która pozwala jej pokazać, że patologie związane $z$ funkcjonowaniem prawa, choć istotne, nie powinny przyćmiewać istoty samego prawa i jego znaczenia dla społeczeństwa. Fakt, że autorka nadaje duże znaczenie opisywanemu lokalnemu i autonomicznemu systemowi opieki nad ubogimi, a przede wszystkim uprawnieniu do zapomogi, staje się zrozumiały, gdy porównamy ów system z systemem powstałym w drugiej połowie dziewiętnastego wieku, którego znakiem rozpoznawczym stały się domy pracy przymusowej.

Początek tego drugiego zwiastuje uchwalenie przez Parlament poprawki do ustawy o ubogich (Poor Law Amendment Act) w 1834 roku. Autorka nazywa ją „dzieckiem zrodzonym

\footnotetext{
${ }^{4}$ Do drugiej połowy dziewiętnastego wieku dzieci z nieprawego łoża posiadały osiedlenie w parafii, w której się urodziły, a co za tym idzie, to właśnie owa parafia zmuszona była udzielać im świadczenia w razie ich popadnięcia w ubóstwo.
} 
z Benthamowskiego pozytywizmu i reformistycznych teorii ekonomii politycznej Wigów" (Charlesworth 2010, 4). Poprawka ta przenosiła odpowiedzialność za pomoc ubogim ze szczebla lokalnego na ogólnokrajowy - miejsce dawnej mapy parafii zajął nowy podział administracyjny na związki (Poor Law Unions) podlegające władzy krajowej. Ustawa stanowiła ponadto, że pomoc może być udzielana tylko w tworzonych przez owe związki domach pracy o surowym rygorze. Miejsca te były spełnieniem najczarniejszego panoptycznego koszmaru „rozdzielano w nich rodziny, a więzienny reżim, dieta i dyscyplina obowiązywała każdego, od niemowlęcia po starca” (Charlesworth 2010, 9). Część angielskich obszarów opierała się porządkowi wprowadzanemu przez ustawę, miało miejsce również wiele lokalnych protestów ludności przeciwko zakładaniu domów pracy (Charlesworth 2010 150-159). Koniec końców jednak tendencja do uniformizacji wzięła górę - w 1865 roku ostatecznie odebrano urzędnikom parafialnym wszelkie kompetencje związane $z$ opieką nad ubogimi i scedowano je na związkowych opiekunów (Charlesworth 2010, 64).

Co zdaniem Charlesworth oznaczało to dla ubogich? Ostateczne zwycięstwo zasad ekonomii politycznej i wolnego rynku, które nie uznając żadnych praw ani obowiązków, odebrały biedocie możliwość samodzielnego i wolnego utrzymania się z pomoca zasiłku. Domy pracy wprowadzały nową regułę, zgodnie z którą jedyna droga ratunku dla wymagających wsparcia wiodła przez odgórnie zorganizowany i oparty na cudzych środkach produkcji reżim pracy. Wcześniejsza postać prawa ubogich, jako rodzaju urządzenia społecznego, opierała się na zupełnie innych fundamentach - pozwalało ono w pewnym zakresie na partycypację samych zainteresowanych w procesie przyznawania pomocy (ubiegający się o pomoc mógł uczestniczyć w postępowaniu na każdym jego szczeblu, przedstawiać dowody i spierać się z urzędnikami). Przyznawana zapomoga miała, co do zasady, służyć przywróceniu możliwości samodzielnego utrzymania się. Powyższe wnioski dotyczące prawa ubogich wynikaja wprost z perspektywy przyjętej przez autorkę, która idąc śladami Henry’ego Maine’a, „zaczyna jurydyczną analizę od badania społecznych ustaleń służących zachowaniu porządku, w celu odnalezienia uzasadnień dla istnienia i natury prawa" (Charlesworth 2010, 17-18). Wcześniejsze prawo ubogich tworzyło zbiór zróżnicowanych mikroukładów utrzymywania biednych, które, jak już zauważyliśmy, nie były odporne na zepsucie, ale mimo to dawały potrzebującym większą autonomię i możliwość stawiania oporu.

Wprowadzony później system był przesiąknięty „maltuzjańskimi lękami przed niekontrolowanym wzrostem populacji [...] i coraz częstszymi wybuchami gwałtownego niezadowolenia zarówno wiejskiej, jak i miejskiej populacji robotniczej" (Charlesworth 2010, 185). Remedium na ten strach stanowiło stworzenie „nowoczesnych” domów pracy, które de facto były rezerwuarem taniej siły roboczej - w tym kontekście Marks opisuje procedery sprowadzania dzieci z domów pracy bezpośrednio do fabryk (Marks 1951, 817-818). Autorka dodaje ponadto, że w samych tych domach dochodziło często do nadużyć władzy 
i przypadków śmierci z wyczerpania. Stała za tym niedostateczna możliwość ingerencji w postępowanie związków nadzorujących domy pracy, których decyzje były znacznie mniej transparentne, a działania podlegały zewnętrznej kontroli w mniejszym stopniu, niż miało to miejsce w przypadku urzędników parafialnych. Z samej swojej zasady jednak domy pracy miały dyscyplinować biedotę rozleniwioną przez parafialną zapomogę - warunki wewnątrz instytucji miały być gorsze niż te poza nią, co w założeniu powinno zachęcać biedotę do powrotu na wolny rynek i motywować ją do podjęcia pracy (Charlesworth 2010, 14). Autorka tak podsumowuje skutki tej zmiany:

przejście od prawa ubogich jako common law do ujmowania tego prawa jako przedmiotu prawa publicznego (administracyjnego) gruntownie zmieniło jurystyczne perspektywy spojrzenia na kwestie prawa ubogich; spowodowało ono, że uwaga prawa z bezpośrednich potrzeb finansowych indywidualnego ubogiego w jego lub jej miejscu osiedlenia przesunęła się na to, jak rząd wykorzysta swoją władzę (Charlesworth 2010, 23).

Reforma, sławiona jako kolejny krok ku nowoczesności i większej gospodarności, ukazała swoje oblicze Meduzy nie tyle w przypadku Anglii, co Irlandii. Zaledwie w cztery lata po uchwaleniu nowego prawa ubogich Parlament w Westminsterze wydał „Irlandzkie prawo ubogich" (Irish poor law), stanowiące implementację rozwiązań angielskich (por. Crossman 2008). O ile jednak w Anglii system domów pracy dopasowany był do podziału administracyjnego, o tyle w Irlandii - gdzie funkcjonowało zamknięte finansowanie i odmienne prawa zwyczajowe - okazał się całkowicie niewydolny (Charlesworth 2010, 178). Tę niewydolność obnażył Wielki Głód lat czterdziestych dziewiętnastego wieku, który do tej pory niczym zadra tkwi w pamięci ludowej. Inaczej niż w Anglii, gdzie wciąż istniał oddolny system wspomagania biednych z finansowaniem zależnym od potrzeb, w Irlandii pomoc udzielana była tylko w przepełnionych domach pracy $\mathrm{i}$ w bardzo rzadkich przypadkach poza nimi (Crossman 2008). Według Charlesworth doprowadziło to do sytuacji, w której coraz więcej populacji żyło w skrajnej nędzy, liczba zgonów wzrastała z dnia na dzień, podczas gdy sama ustawa „pozwalała rządowi brytyjskiemu i jego irlandzkiej administracji zrzucić z siebie odpowiedzialność za zapobieganie śmierci głodowej i jednocześnie pozostać w granicach tego, co stanowiło prawo ubogich w Irlandii" (Charlesworth 2010, 179). Jak stwierdza autorka, ten tragiczny przykład ujawnia ogromne znaczenie prawa do zapomogi, które mogło być aktywnie egzekwowane przez samych zainteresowanych i w ramach którego obowiązek pomocy pozostawał po stronie władz.

Wnioski kończące Welfare's Forgotten Past sa, mimo bogactwa przeprowadzonych tu analiz, rozczarowujące. Trudno zresztą spodziewać się fajerwerków - autorka stwierdza na początku tomu, że jej praca „mieści się w paradygmacie liberalnym [i] stanowi celebrację wartości uprawnienia do zapomogi” (Charlesworth 2010, 35), jak również że „,nie ma tu rozwiązań, a »historia« nie oferuje żadnych pouczeń poza tym, że od stuleci wciąż pomagaliśmy 
ubogim w Anglii i Walii bez względu na ekonomiczne i polityczne kryzysy" (Charlesworth 2010, 8). W świetle współczesnych prac poświęconych przemianom społeczeństwa przedkapitalistycznego, które kontynuują badania Marksa nad tak zwaną akumulacja pierwotna, stwierdzenie, że ,jesteśmy winni współczesnym ubogim” (Charlesworth 2010, 204) pamięć o dawniej istniejącym uprawnieniu do zapomogi klasy ludowej i robotniczej, wypada nadzwyczaj skromnie. Książka uderza jednak w obraz biedoty jako społecznego „pasażera na gapę". Pokazuje moment, w którym to sama władza państwowa dokonała przekształcenia ubogich w bezwolny przedmiot zarządzania i dyscyplinowania, odbierając im podstawę autonomii, jaką było substancjalne prawo do ubiegania się o opiekę bez towarzyszącego mu obowiązku podporządkowania się reżimowi domów pracy.

Pamięć o ubogich i zasadniczej zmianie ich sytuacji może natomiast skłaniać nas do przemyślenia roli, jaką w procesie kształtowania się nowoczesnego kapitalizmu odegrała władza państwowa i narzucana przez nią dyscyplina. Zdaniem Silvii Federici

wdrożenie publicznej opieki było punktem zwrotnym w stosunku między robotnikiem a kapitałem i w rozumieniu funkcji państwa. Po raz pierwszy uznano wtedy niemożliwość utraymania systemu kapitalistycznego rządzącego tylko za pomoca głodu i strachu. Był to również pierwszy krok w wykształcaniu państwa jako gwaranta stosunku klasowego i jako głównego nadzorcy reprodukcji i dyscyplinowania siły roboczej (Federici 2009, 84).

Welfare's Forgotten Past potwierdza tę tezę, pokazując stopniowe zacieśnianie się kontroli państwowej nad egzystencją ubogich i środkami ich utrzymania, a także jej udział w narzucaniu reżimu pracy oraz zasadniczym przeorganizowaniu siły roboczej.

Kolejny aspekt postępującego podporządkowania biedoty odgórnej władzy państwa i kapitału obrazuja momenty, w których analizy systemu opieki nad ubogimi Charlesworth zbiegaja się z komentarzami dotyczącymi postępujących grodzeń (enclosures). Warto tu zaznaczyć, że prawo do zapomogi było jednym z nielicznych praw zwyczajowych, które nie tylko przetrwało grodzenia, ale również zyskało legalny status dzięki uznaniu ich przez Sąd Koronny. Przekształcenia własności ziemskiej i nowy podział obszarów znajdujących się we władzy państwowej doprowadziły do wygaśnięcia zwyczajowych sposobów zdobycia środków utrzymania związanych z funkcjonowaniem gospodarstwa. Łatwo można wyjaśnić tę sytuacje - postępowanie przed Sądem Koronnym wymagało środków finansowych, których klasa ludowa nie posiadała (Charlesworth 2010,38), a nowa forma własności z zasady wykluczała wspólistnienie tych praw zwyczajowych. W mikroekonomię klasy ludowej najbardziej uderzyła jednak utrata współwłasności ziemskich, które określały „,system dzierżawy obszaru, a nie rodzaj obszaru, w którym własność ziemska może przypadać jednej ze stron, jednak inne strony mają tytuł do różnych praw z nią związanych, takich jak wypasanie czy ścinanie drewna na opał" (Linebaugh 2014, 150-151). Jak zatem zauważa Charlesworth, dobra wspólne były „zabezpieczeniem, rezerwą i najstarszym elementem dawnej ekonomii prawnej, która po prostu 
pozwalała chłopstwu żyć z mniejszym zapotrzebowaniem na zapomoge" (Charlesworth 2010, 108). Choć ich likwidacja zniszczyła pewien sposób życia i przyniosła negatywne konsekwencje dla wszystkich chłopów, to właśnie najuboższa warstwa społeczeństwa najbardziej na niej ucierpiała.

W Welfare's Forgotten Past brakuje rzetelnej analizy wpływu grodzeń i postępującej destrukcji praw zwyczajowych na funkcjonowanie systemu opieki nad biednymi, jednak sama autorka zdaje się sugerować taki związek, odwołując się do prac E.P. Thompsona (1990) i Douglasa Haya (2011), którzy „zauważają, że podatek na biednych utrzymywał się na niskim poziomie, gdy ubodzy mieli dostęp do takich »zasobów« [dóbr wspólnych - przyp. AP]” (Charlesworth 2010, 112). W Marksowskim Kapitale znajdujemy również uwagę o tym, że

przywłaszczenie gruntów gminnych i towarzyszący mu przewrót w rolnictwie oddziałały tak silnie na sytuację robotników rolnych, że [...] płaca ich w latach 1765-1780 poczęła spadać poniżej minimum i musiała być uzupełniania ze środków dobroczynności publicznej (Marks 1951, 785).

Możemy więc założyć, że w momencie utraty szeroko rozumianych dóbr wspólnych głównym legalnym sposobem na samodzielne utrzymanie się w przypadku niedostatku było pobieranie zapomogi. Co za tym idzie, doszło do obciążenia parafii, a co ważniejsze - odmowa zasiłku oznaczała konieczność zmiany miejsca zamieszkania, podjęcia pracy na niekorzystnych warunkach czy wreszcie szukania źródeł utrzymania na granicy prawa (por. Rule 2011) lub poza nim (por. Hay 2011, Linebaugh 2006, 184-225). Tylko w tym kontekście możemy w pełni zobaczyć rolę prawa do zapomogi jako spoiwa podtrzymującego lokalną i autonomiczną mikroekonomię parafii.

Przejście od parafialnej zapomogi do domów pracy, od poziomu lokalnego i autonomicznego do poziomu scentralizowanej administracji doprowadziło do ostatecznego zniszczenia chłopskiej gospodarki i stanowiło kolejny krok w kierunku uformowania „wolnego” robotnika najemnego. Świadczy o tym sama reakcja klasy ludowej: „opozycja nie była niczym niezwyczajnym czy nietypowym; wyrażała głębokie poczucie straty, kradzieży dziedzictwa wiejskiej biedoty" (Charlesworth 2010, 196). Jak udowadnia jednak autorka, zapomina się o tym, że „ubodzy opierają się także dogłębnie rzeczywistej utracie statusu prawnego w obrębie systemu prawa ubogich" (Charlesworth 2010, 197). Choć sama Charlesworth nie artykułuje explicite związków między kapitałem a władzą państwową, Welfare's Forgotten Past można czytać nie tylko jako przewodnik po zapomnianej przeszłości państwa opiekuńczego, ale także jako zagubiony na śmietniku historii opis dziejów akumulacji pierwotnej. Rekonstrukcja Charlesworth przedstawia bowiem nie tylko zwyciesstwo Benthamowskiego utylitaryzmu i zasad rynkowych nad tradycją ale także działanie państwowej przemocy (state-Gewalt) jako jednego z instrumentów akumulacji pierwotnej (por. Tomba 2013, 
167), a więc i aparatu służącego do pozbawiania angielskich mas środków utrzymania. Odczytanie przemocy państwowej jednocześnie jako narzędzia zwiększania kontroli - przez przekształcenie biedoty w przedmiot administrowania - i jako narzędzia akumulacji pierwotnej - likwidującego przestrzenie autonomii w obrębie ekonomii - pozwala lepiej ugruntować krytykę współczesnych wizji polityki opieki nad ubogimi. Odzyskiwana w Welfare’s Forgotten Past przeszłość biedoty, której odebrano środki samodzielnego utrzymania w postaciach dóbr wspólnych i lokalnej, autonomicznej zapomogi, kwestionuje wychowawczą i mobilizująca funkcję państwa przezwyciężającego rzekomą pasywność mas, do której powstania w pewnym stopniu samo się przyczyniło. 


\section{Wykaz literatury}

A Charlesworth, Lorie. 2001. "The Poet and The Poor Law. Reflections Upon John Clare's The Parish." Liverpool Law Review 23: 167-178.

Charlesworth, Lorie. 2010. Welfare's Forgotten Past. A Socio-Legal History of Poor Law. Oxford: Routledge.

Crossman, Virginia. 2008. The Poor Law in Ireland, 1838-1948. http://www.history.ac.uk/ihr/Focus/welfare/articles/crossmanv.html.

Federici, Silvia. 2009. Caliban and the Witch. New York: Autonomedia.

Hay, Douglas. 2011. "Property, Authority and the Criminal Law." W Douglas Hay, Peter Linebaugh, John G. Rule, E.P. Thompson i Cal Winslow. Albion's Fatal Tree. LondonNew York: Verso.

Hüning, Simone Maria. 2015. "Criminalizing Poverty and Fragmenting the City in Brazil." Theory, Culture and Society 0(0): 1-6.

Marks, Karol. 1976. „Obrady szóstego Landtagu reńskiego. Artykuł trzeci: Debaty nad ustawą o kradzieży drzewa". W Karol Marks i Fryderyk Engels. Dziieła, t. 1. Warszawa: Książka i Wiedza.

Katrougalos, George i Gabriella Lazaridis. 2003. Southern European Welfare States. New York: Palgrave Macmillan.

Linebaugh, Peter. 2006. The London Hanged. London-New York: Verso.

Linebaugh, Peter. 2014. Stop, Thief! The Commons, Enclosures and Resistance. Oakland: PM Press.

Marks, Karol. 1980. The Emancipation Question. http://marxists.anu.edu.au/archive/marx/works/1858/12/31.htm

Marks, Karol. 1951. Kapitat. Krytyka ekonomii politycznej, t. 1. Proces wytwarzania kapitału. Warszawa: Książka i Wiedza.

Musterd, Sako i Wim Ostendorf. 2003. Urban Segregation and The Welfare State. Oxford: Routledge.

Rule, John. 2011. “Wrecking the Coastal Plunder.” W Douglas Hay, Peter Linebaugh, John G. Rule, E.P. Thompson i Cal Winslow. Albion's Fatal Tree. London-New York: Verso.

Thompson, E. P. 1990. Whigs and Hunters: The Origin of the Black. Act. London: Penguin Books. Tomba, Massimiliano. 2013. Marx's Temporalities. Chicago: Haymarket Books.

Tosi, Antonio. 1996. "The Excluded and the Homeless: the Social Construction of The Fight Against Poverty in Europe." W Urban Poverty and The Underclass, red. Enzo Mingnione. Oxford: Blackwell Publishers.

Wacquant, Loïc. 2009. Więzienia nędzy. Tłum. Michał Kozłowski. Warszawa: Książka i Prasa. 
Anna Piekarska - filozofka polityki. Studentka Centrum Studiów Latynoamerykańskich na Uniwersytecie Warszawskim. Członkini redakcji Praktyki Teoretycznej.

\section{DANE ADRESOWE:}

Anna Piekarska

Centrum Studiów Latynoamerykańskich UW

ul. Smyczkowa 14

02-678 Warszawa

EMAIL: piekarska.ania@gmail.com

CYTOWANIE: Piekarska, Anna. 2015. Ludowe państwo dobrobytu. Praktyka Teoretyczna 4(18): 228-239.

DOI: $10.14746 /$ prt.2015.4.11

\section{AUTHOR: Anna Piekarska}

TITLE: Welfare State of the People

ABSTRACT: The article is an attempt to reconstruct the transformation of poor laws in precapitalist England based on Lorie Charlesworth's work Welfare's Forgotten Past. The substantial contexts of this reconstruction are the history of enclosures and commons as well as the concept of so-called primitive accumulation, originating from Karl Marx. The major scope of interest is the conjunction of the loss of the poor's subjective rights and the penalization of the poor according to vagrancy laws.

KEYWORDS: Lorie Charlesworth, enclosures, poor, commons, legal history, England 